\title{
Evaluation of Antimicrobial-Antibiofilm Activity of a Hydrogen Peroxide Decontaminating System Used in Dental Unit Water Lines
}

\author{
Germano Orrù $^{1, *}$, Susanna Del Nero ${ }^{2}$, Enrica Tuveri ${ }^{1}$, Maria Laura Ciusa ${ }^{1}$, Francesca Pilia ${ }^{1}$, Matteo \\ Erriu $^{1}$, Ginevra Orrù ${ }^{3}$, Manuele Liciardi ${ }^{3}$, Vincenzo Piras $^{1}$ and Gloria Denotti ${ }^{1}$
}

\author{
${ }^{I}$ OBL (Oral Biotechnology Laboratory), Dipartimento di Chirurgia e Scienze Odontostomatologiche, Universita' degli \\ Studi di Cagliari, Cagliari, Italy; ${ }^{2}$ CEFLA Dentale, Imola, Italy; ${ }^{3}$ Istituto Zooprofilattico Sperimentale della Sardegna, \\ Cagliari, Italy
}

\begin{abstract}
A dental unit water line (DUWL) equipped with a device designed to automatically and continually flush a bacteriostatic solution of hydrogen peroxide (WHE) and a discontinuous disinfecting system (BIOSTER) was evaluated. In the first instance a preliminary sensitivity test on a large number of microorganisms (bacteria and fungi) was tried with a $\mathrm{H}_{2} \mathrm{O}_{2}$ range from 100 to $800 \mathrm{ppm}$. The bacteria frequently reported in DUWL (including Pseudomonas spp, Streptococcus spp., Staphylococcus spp., E. coli) and some periodontal pathogens showed a minimum inhibitory concentration from 100 to $300 \mathrm{H}_{2} \mathrm{O}_{2}$ ppm (also including $M$. marinum and $C$. albicans). However, $\mathrm{H}_{2} \mathrm{O}_{2}$ did not show any inhibitory effects against: A. actinomycetemcomitans, $C$. glabrata $C$. parapsilos, F. nucleatum, M. micros. In a second step, the DUWL was experimentally infected with $S$. faecalis, E. coli, P. aeruginosa, S. aureus. After disinfection steps with $3 \% \mathrm{H}_{2} \mathrm{O}_{2}$, the inhibitory effect on planktonic forms and on sessile biofilm was measured. In a third step, the count of 16S rRNA gene copies by real time PCR at different points of the DUWL described an accrue of bacterial slime in "hot spot" regions characterized by irregular/slow water flux (valves, elbows). However these results suggest that hydrogen peroxide is not only able to inhibit bursts of planktonic bacteria inside the DUWL, but that it could also be effective against sessile biofilm containing heterotrophic microorganisms derived from domestic water line contamination. In addition some oral pathogens could be contaminating and surviving in DUWL.
\end{abstract}

Keywords: Dental Unit Water Lines, Hydrogen Peroxide, Biofilm.

\section{INTRODUCTION}

Dental units are the core of dental clinics. The handpieces (air-water syringes, ultrasonic scalers, prophy-angles, turbines, micromotors) are connected to dental units by a network of small-bore plastic tubes through which water and air travel to activate or cool the instruments. Different authors have shown that this system is extensively colonized by microorganisms with at least 40 different species including: oral streptococci, Pseudomonas spp., Enterobacteria, Candida albicans, Legionella pneumophila and nontuberculous Mycobacterium spp. [1-4]. Inside this waterline, chemical-physical conditions, such as: water flux, temperature, variations in tube surfaces and the chemical composition of the tubes, vary greatly in different parts of the DUWL; consequently the resident bacterial biofilm shows different qualitative/qualitative biological characteristics [5, 6]. These microbial biofilms comprise mainly a matrix of highly hydrated complex exopolysaccharides secreted by bacteria, housing micro-colonies and single cells, heterogeneously interspersed by channels or pores [7, 8].

Planktonic forms of microorganisms and pieces of biofilm are shed from here and seed biofilm-forming microorganisms elsewhere in the waterline network. The same

*Address correspondence to this author at the Dipartimento di Chirurgia e Scienze Odontostomatologiche, Università degli Studi di Cagliari, Via Binaghi 4, 09121 Cagliari-Italy; Tel: +39 070537413; Fax: +39 070 537437; E-mail: orru @unica.it microorganisms are then transferred directly into the mouths of patients during dental procedures.

The exopolymer matrix can restrict the diffusion of substances and bind antimicrobials. This provides effective resistance for cells enclosed in a biofilm against a large number of antimicrobial molecules [9]. In recent years manufacturers have responded to the evident need for changes in DUWL engineering and design to control DUWL biofilms [10]. Several strategies have been evolved to reduce bacterial colonization and growth, including the use of waterline flushing, independent water reservoir systems, distilled or pasteurized water, ultraviolet light, filtration and periodic or continuous chemical disinfection [11]. Among chemical disinfectants, hydrogen peroxide-based compounds play a central role in disinfection strategies of European leading dental unit manufacturers [12]. Hydrogen peroxide has been shown to possess a wide spectrum of antimicrobial activity, in that it is active against bacteria, yeasts, fungi, viruses and spores [13-15]; normally, these protocols make use of a $0.25-3 \%$ $\mathrm{H}_{2} \mathrm{O}_{2}$ concentration range. The efficacy of hydrogen peroxide depends on many factors, for example: concentration, $\mathrm{pH}$, temperature, reaction time, use in combination with physical agents [16]; moreover it depends on bacterial/viral concentration, the microbial species under consideration and their biological phase (e.g. spore or vegetative status), the presence of organic substances, the nature of the surface to be treated (presence of pores, micro-cracks) and bacterial genetic proprieties [17]. 


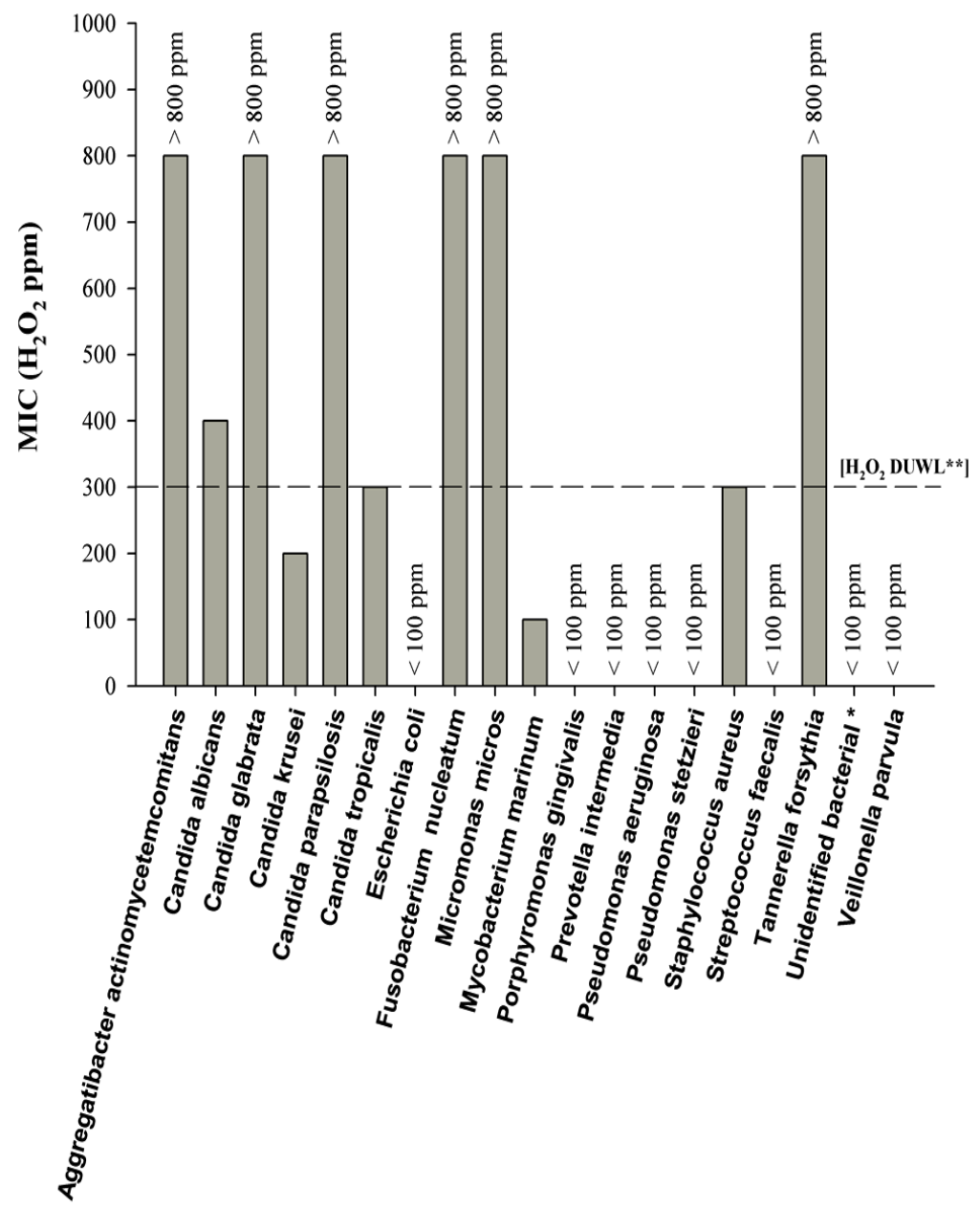

Fig. (1). $\mathrm{H}_{2} \mathrm{O}_{2}$ susceptibility pattern of the most common microorganisms isolated in DUWLs.

* Corresponding to the 16S rRNA, sequence deposited in GenBank as accession n. GU 057339, GU 057340, GU 057341

** $\mathrm{H}_{2} \mathrm{O}_{2}$ concentration normally used in a continuous mode inside the DUWL, according to the manufacturer's instructions.

The action of $\mathrm{H}_{2} \mathrm{O}_{2}$ on microbes is due to the presence of the hydroxyl radical $(\mathrm{OH} \cdot)$ in the solution. The hydroxyl radical is said to be the strongest oxidant known; transition metals are believed to catalyze the formation of the hydroxyl radical. It can attack membrane lipids, DNA, and other essential cell components. Different mechanisms are described for biofilm inhibition by $\mathrm{H}_{2} \mathrm{O}_{2}$. Recent studies showed in Staphylococci a reduction (by $\mathrm{H}_{2} \mathrm{O}_{2}$ ) of icaADB cassette expression (involved in polysaccharide intercellular adhesion) [18]. Moreover, in Gram negative bacteria the production of internal $\mathrm{H}_{2} \mathrm{O}_{2}$ by AlpP-gene may play an important role in biofilm formation: some of the biofilm-forming cells are killed by internally produced $\mathrm{H}_{2} \mathrm{O}_{2}$, and this leads to differentiation, dispersal, and phenotypic variation among dispersal cells [19].

Based on previous experiments described in different publications $[12,20,21]$, this work evaluates by a in vitro platform: (a) large numbers of microorganisms tested with different $\mathrm{H}_{2} \mathrm{O}_{2}$ concentrations, (b) a DUWL contamination model performed using a mix suspension of four microorganisms: Escherichia coli, Pseudomonas aeruginosa, Streptococcus faecalis, Staphylococcus aureus, (c) DUWL biofilm mass monitoring, using molecular and cultural methods.

\section{MATERIALS AND METHODOLOGY}

\section{Strains Used in this Work}

DUWL microflora have been described by other authors. It has been demonstrated that bacterial forms are the dominant part in these biofilms, while fungi and protozoa are less common. However, following the latest publications, we used the following species, Fig. (1).

1. Gram positive bacteria: Staphylococcus aureus ATCC 6538, Streptococcus (Enterococcus) faecalis ATCC 29212 [22, 23].

2. Gram negative bacteria: heterotrophic aerobic species are the most represented in DUWL. We used: Escherichia coli ATCC 7075, Pseudomonas aeruginosa ATCC 27853, Pseudomonas stutzeri, isolate OG7 and unidentified bacterial species, isolates: OG4-OG5 (these three strains were isolates from DUWL domestic water line and characterized by $16 \mathrm{~S}$ rRNA sequence). We also evaluated a sensitivity test with 
Gram negative periodontal pathogens: Prevotella intermedia CCUG 2404 (Culture Collection, University of Göteborg, Sweden), Aggregatibacter actinomycetemcomitans, CCUG 37005, (genotype 652) Porphyromonas gingivalis CCUG 25893, Tannerella forsythensis cip 105220 (Institut Pasteur, Paris, France), Fusobacterium nucleatum DSMZ 19508, Parvimonas micra DSMZ 20468, Veillonella parvula DSMZ 2008 (Deutsche Sammlung von Mikroorganismen und Zellkulturen $\mathrm{GmbH}$ ).

3. Fungi: Candida albicans has been associated with dental unit water systems [24]; in this work 5 different oral clinical isolates of Candida spp. (designed from OG11 to OG15) were tested with a $\mathrm{H}_{2} \mathrm{O}_{2}$ sensitivity test. These specimens were plated in Sabouraud glucose agar for $48 \mathrm{~h}$ at $35^{\circ} \mathrm{C}$ (Microbiol, Uta, Cagliari, Italy). The colonies were identified with an API ID32C system (Biomerieux, St Louis, MO) and maintained at $-20^{\circ} \mathrm{C}$ in skimmed milk (Oxoid, Basingstoke, UK).

4. Mycobacteria: in accordance with the presence of non tuberculosis Mycobacterium spp in DUWL [25], a simulation model with Mycobacterium marinum was performed. Aerobic bacteria were cultured in Müller Hinton agar, (MH Microbiol, UTA, Cagliari Italy). Anaerobic bacteria were maintained at $-80^{\circ} \mathrm{C}$ in vials containing Schaedler Broth with 15\% glycerol and cultured in Columbia agar blood (Microbiol, UTA, Cagliari, Italy) at $37^{\circ} \mathrm{C}$ with $5 \% \mathrm{CO}_{2}$ in jar (Biomérieux Marcy l'Etoile, France). M. marinum was cultured in tubes of Middlebrook 7H10 agar with OADC supplement (Microbiol, UTA, Cagliari, Italy) and stored at room temperature. Visible colonies were observed after 2-4 weeks of incubation. Nucleotide sequence accession numbers: the 16S rRNA gene sequences from Gram negative bacteria isolates OG4, OG5, OG6 have been deposited in GenBank under the following accession numbers: GU057341, GU057340, GU057339.

\section{$\mathrm{H}_{2} \mathrm{O}_{2}$ in vitro Susceptibility Testing}

Baseline MICs were determined in accordance with the Committee for Clinical Laboratory Standards [NCCLS, http://www.clsi.org/] by using a broth dilution method.

$\mathrm{H}_{2} \mathrm{O}_{2}$ was diluted in tubes containing $5 \mathrm{ml}$ of liquid medium with a concentration range from 100 to $800 \mathrm{ppm}$ (Fig. 1). These tubes contained an inoculum titre of $10^{6} \mathrm{CFU} / \mathrm{ml}$ for bacteria and $10^{5} \mathrm{CFU} \mathrm{ml} \mathrm{for} \mathrm{Candida} \mathrm{spp.}$

\section{$\log _{10}$ Bacterial Reduction (LR)}

The LR value (logarithm of the bacterial reduction) was performed by using a DUWL disinfection system (simulator) comprising: a WHE system, approved by DVGW (Deutsche Vereinigung des Gas- und Wasserfaches) for the continuous addition of $\mathrm{H}_{2} \mathrm{O}_{2}$ at a final concentration of $300 \mathrm{ppm}$ and a BIOSTER system for dental unit water line disinfection, which draws $3 \% \mathrm{H}_{2} \mathrm{O}_{2}$ from a dedicated tank and leaves it to stand within the dental unit water lines for a time pre-set by the dental operator, within a chosen time range (not shorter than 5 minutes and not longer than 30 minutes; standard con- tact time 10 minutes), after which dental unit water lines are automatically flushed with water from the public water system. WHE (Water Hygienisation System) and BIOSTER are the commercial names of optional hygiene devices which may be optionally present on CEFLA Dentale dental units.

$100 \mathrm{ml}$ of Müller Hinton Broth was inoculated with a mix of the following bacterial species: $P$. aeruginosa, $E$. coli, S. aureus, S. faecalis until a final concentration of $10^{8}$ $\mathrm{CFU} / \mathrm{ml}$ for each bacterial species. Subsequently, $\mathrm{H}_{2} \mathrm{O}_{2}$ was added to the different tubes by the simulator with a concentration of $3 \%$, when used for final disinfection, or at 300 ppm, when used in a continuous manner; $100 \mu$ l was plated in MH Agar every 20 minutes for 2 hours. The colonies on each plate were counted after incubation at $37^{\circ} \mathrm{C}$ for 48 hours. The result was expressed as the average number of colony forming units per $\mathrm{ml}$ of sample computed from the triplicate plates (Fig. 2).

\section{Biofilm Model Construction Inside the Complete DUWL}

For our study we used a complete prototype of Stern 300 dental unit (CEFLA Dentale), provided with a BIOSTER system integrated into the hydro group and a WHE system with separate joint, Fig. (3).

A mix of the four species, previously described for LR, was used as the contaminant system.

The artificial biofilm was constructed as follows: (a) inoculation of ten liters of a suspension of $10^{6} \mathrm{CFU} / \mathrm{ml}$ for each species in saline solution into the DUWL, (b) after four weeks, bacterial vitality was controlled by plating $1 \mathrm{~cm}^{2}$ of DUWL biofilm specimen in Müller Hinton agar (c) subsequently the DUWL tubes were reconditioned by threefold washing with a new sterile saline solution followed by a disinfection program with $3 \% \mathrm{H}_{2} \mathrm{O}_{2}$ according to the DUWL manufacturer's instructions.

$1 \mathrm{ml}$ of DUWL water post disinfection was plated in Müller Hinton agar for evaluation of bacterial vitality presence. Successfully we evaluated the possible presence of signs of bacterial biofilm; the biofilms were scraped at 26 different points from 1 sq. cm surfaces, by using a sterile swab scraper (Nunc, Wiesbaden, Germany). The swab was suspended in $1.5 \mathrm{ml}$ of sterile saline solution: $1 \mathrm{ml}$ was used for strain isolation by plating in Müller Hinton agar and 0.4 $\mathrm{ml}$ was used for DNA extraction [23]. Biofilm bacterial mass was measured by a real time PCR procedure.

\section{Real Time PCR}

As described in a previous publication [23], real time PCR were performed by using OG 33 (5' GACTACCAGGGTATCTAATC -3') and OG 123 (5'AGCAGCCGCGGTAATA -3') primers, these oligos were designed by using a bacterial common (non variable) region of the 16S rRNA gene sequence, extracted from the NCBI database GenBank with accession number AY692453.

\section{RESULT AND DISCUSSION}

Microcolonies of proliferating micro-organisms forming a highly resistant biofilm $[5,26]$ on the inner surface of DUWL water lines are thought to be the source of bacterial contamination within the dental unit water supply. These biofilms are heterogeneous in species and morphology and 


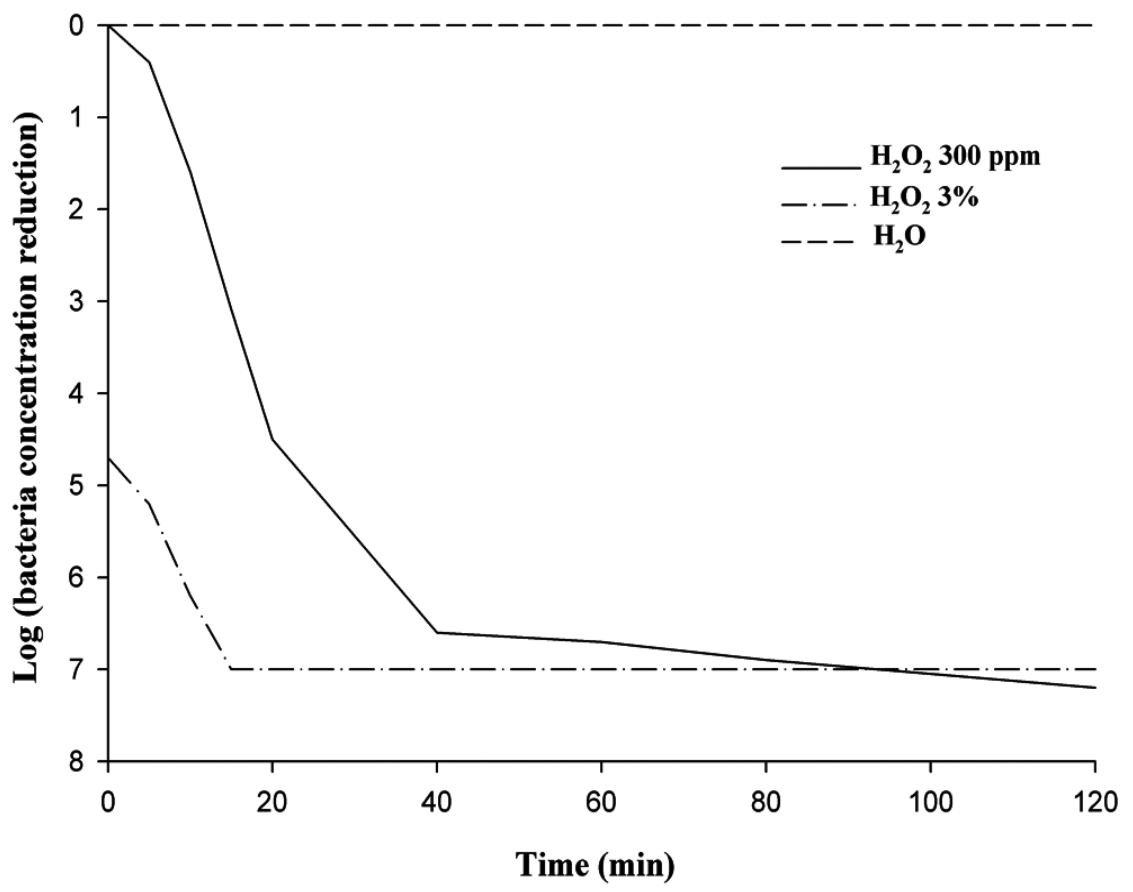

Fig. (2). Geometric mean of viable bacteria reduction Log, corresponding to bacterial suspension composed of: E. coli, P. aeruginosa, S.aureus and S. faecalis.

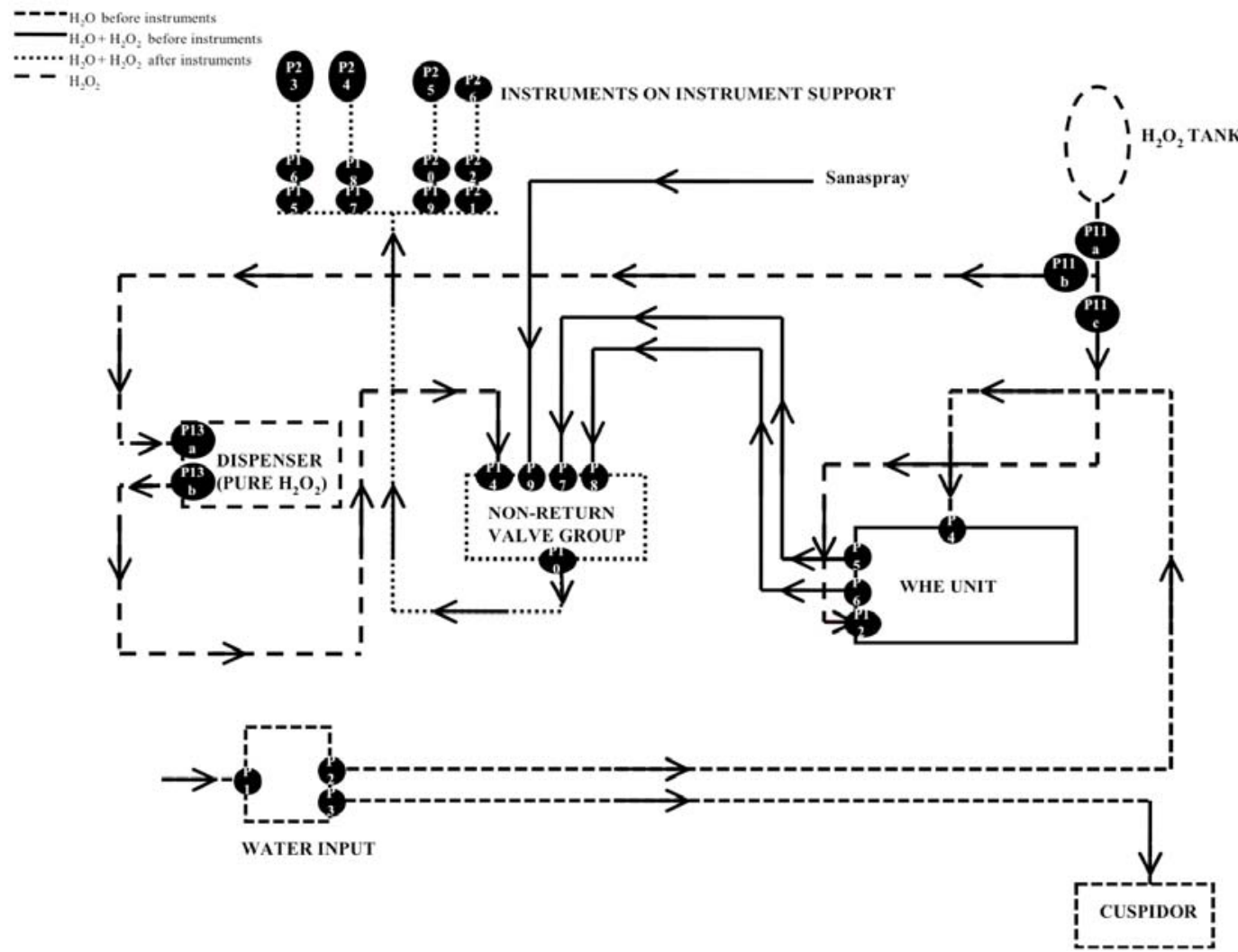

Fig. (3). Schematic representation of the DUWL used in this work, the black circles labelled from 1 to 26 , correspond to specimen points.

are enveloped in a polysaccharide slime layer known as a glycocalyx. Numerous procedures have been suggested for overcoming the problem of the microbial contamination of dental unit water supplies [27]. The Centers for Disease
Control (CDC) recommend that all water lines should, at the very least, be made to run and discharge water for several minutes at the beginning of each day and for a shorter interval between patient appointments [28]. 
One problem of protocols based on chemical agents for the control of biofilm is that they have to be bactericidal but not toxic to patients. The chemical treatment detaches biofilm and discourages its subsequent reformation, while protecting the dental unit's internal components from corrosion. If the chemical agent is delivered continuously in treatment water, it is inexpensive and easy to use [11].

Among the micro-organisms capable of transmitting cross-infections, it is possible to find $[10,24,25,29]$ vegetative bacteria ( $S$. aureus, $P$. aeruginosa, $L$. pneumophila, Mycobacterium spp. and others), fungi (Candida spp.), and viruses with abundant lipidic components (HIV; HCV; HBV etc.). In this work we evaluated the $\mathrm{H}_{2} \mathrm{O}_{2}$ activity following three different procedures.

\section{(a) Large Numbers of Microorganisms Tested In Vitro with Different $\mathrm{H}_{2} \mathrm{O}_{2}$ Concentrations}

We evaluated the effectiveness of a disinfection system based on the addition of $\mathrm{H}_{2} \mathrm{O}_{2}$ in continuous with $\left[\mathrm{H}_{2} \mathrm{O}_{2}\right]$ at $300 \mathrm{ppm}$. In the first step a total of 19 different strains were tested by the $\mathrm{H}_{2} \mathrm{O}_{2}$ susceptibility test using $\left[\mathrm{H}_{2} \mathrm{O}_{2}\right]$ from 100 to $800 \mathrm{ppm}$; the results are shown in Fig. (1), the tested microorganisms can be classified into 4 groups: (I) highly sen$\underline{\text { sitive, }}, \mathrm{MIC} \leq 100 \mathrm{ppm}$ such as $P$. intermedia, $P, \underline{\text { gingivalis } V}$. parvula, E. coli, Pseudomonas spp, S. faecalis; (II) sensitive, $100<\mathrm{MIC} \leq 300 \mathrm{ppm}, S$. aureus, M. marinum, C. Krusei and C. tropicalis, (III) resistant MIC $>300 \mathrm{ppm}$, C. albicans, (IV) highly resistant, MIC $>800$ ppm, periodontal pathogens: $A$. actinomycetemcomitans $F$. nucleatum, $P$. micra, $T$. forsythia and two Candida spp., C. glabrata, C. parapsilosis. These results have confirmed and extended earlier works on $\mathrm{H}_{2} \mathrm{O}_{2}$ activity against different potential human pathogens described in the DUWL [12-17, 20, 21]. We observed that the majority of species contaminating DUWL through the domestic water line are $\mathrm{H}_{2} \mathrm{O}_{2}$ susceptible if evaluated in the planktonic status in vitro including $P$. aeruginosa and $P$. stutzeri (Fig. 1). However all tested strains showed a complete inhibition with $\left[\mathrm{H}_{2} \mathrm{O}_{2}\right]$ at $3 \%$.

(b) DUWL Simulator Contamination Model Performed Using a Mix Suspension of Four Microorganisms: Escherichia Coli, Pseudomonas aeruginosa, Streptococcus faecalis, Staphylococcus aureus

The kinetics of planktonic bacteria log reduction in the presence of $\mathrm{H}_{2} \mathrm{O}_{2}$ at $3 \%$ and $300 \mathrm{ppm}$ as discontinuous or continuous disinfection respectively, were performed by using a mix of four of these highly sensitive species inoculated inside the DUWL disinfection system (simulator) (Fig. 2). These results suggest that a substantial inactivation of these microorganisms was observed with hydrogen peroxide, a mean of $5 \log$ reduction was shown after 5 and 15 minutes with $3 \%$ and $300 \mathrm{ppm}$ of $\mathrm{H}_{2} \mathrm{O}_{2}$ respectively. This suggests that an initial contamination of these planktonic forms could be quickly inactivated by this DUWL disinfection system.

On the contrary, evaluating the results showed in chapter (a), some Candida spp and some periodontal pathogens showed considerable $\mathrm{H}_{2} \mathrm{O}_{2}$ resistance [20, 30]. Our results suggest a possible risk for contamination and permanence of these microorganisms in DUWL handpieces if the final disinfection is inactive. They can be transferred through the
DUWL from subjects with clinical or subclinical forms of candidosis (C. glabrata, C. parapsilosis) or periodontitis (i.e A. actinomycetemcomitans).

In this context strict control of the final parts of DUWL, i.e. handpieces, is crucial. All handpieces have to be mandatorily submitted to sterilization in a water vapor autoclave.

(c) DUWL Biofilm Mass Monitoring, Using Molecular and Cultural Methods

Later on the set of four aerobic bacteria was used for contamination and subsequent biofilm formation inside DUWL water lines. These species showed good $\mathrm{H}_{2} \mathrm{O}_{2}$ susceptibility if evaluated as planktonic forms (see Fig. 1), but, as reported by Szymańska et al. [2], and other authors, the possibility of the formation of a resistant biofilm from planktonic bacteria is very high, in particular for Pseudomonas spp [17, 31].

Our aim in this part of the experiment was to test $\mathrm{H}_{2} \mathrm{O}_{2}$ susceptibility in sessile biofilm. After the initial inoculum, the bacterial biofilm formed by the four species was let to stand in the dental unit for 4 weeks. First, after the four 4 weeks we checked the vitality of the biofilm present by cultural methods, and they showed a of CFU/cm2 range of $10^{3}$ $5^{*} 10^{7}$ in 26 specimens (by a mean of 3 different countings). Second, a disinfecting step with BIOSTER $\left(3 \% \mathrm{H}_{2} \mathrm{O}_{2}\right.$ with a contact time of 10 minutes) was performed. After the disinfecting cycle the evaluation of the living bacteria was performed. It was encouraging to note a mean of $99,9-100 \%$ inhibitory effect $\left(E\right.$. coli $2 \mathrm{CFU} / \mathrm{cm}^{2}, P$. aeruginosa 0 $\mathrm{CFU} / \mathrm{cm}, S$. aureus $0 \mathrm{CFU} / \mathrm{cm}^{2}$, and $S$. faecalis $5 \mathrm{CFU} / \mathrm{cm}^{2}$ ), in comparison to the titre checked before the disinfecting cycle.

Moreover, we wanted to evaluate the entire bacterial population present (vital + inactivated bacteria). Therefore we performed an evaluation of the biofilm present $\left(\geq 10^{5}\right.$ bacterial genomes $/ \mathrm{cm}^{2}$, limit of detection of the method) by PCR real time at 26 different points in the DUWL after bacterial contamination and subsequent disinfection (Figs. 3 and 4). The greatest amount of critical biofilm mass (inactivated + vital) was reported in the WHE system, 5 out of 6 points. We suspect that the considerable presence of regulation valves/curves, which are able to determine a laminar irregular flow, are responsible for the biofilm formation. In laminar flow conditions, biofilm can flourish with minimal risk of being dislodged. This is one of the principal reasons why the flushing of waterlines can temporarily lower suspended planktonic microorganisms as recommended by the British Dental Association (BDA) and the CDC, although it is not usually effective in removing biofilms [28, 32].

This result is particularly interesting because it shows how a biofilm tends to accumulate in points of the DUWL which are harder to be reached by $\mathrm{H}_{2} \mathrm{O}_{2}$ or which show a lower water flux.

\section{CONCLUSION}

This study has proven the utility of the hydrogen peroxide disinfection system in eradicating biofilm from dental unit waterlines and in controlling the bacterial count in water against several bacterial species. In addition, possible DUWL contamination with some Candida or anaerobic periodontal species in patients remains a central point of 


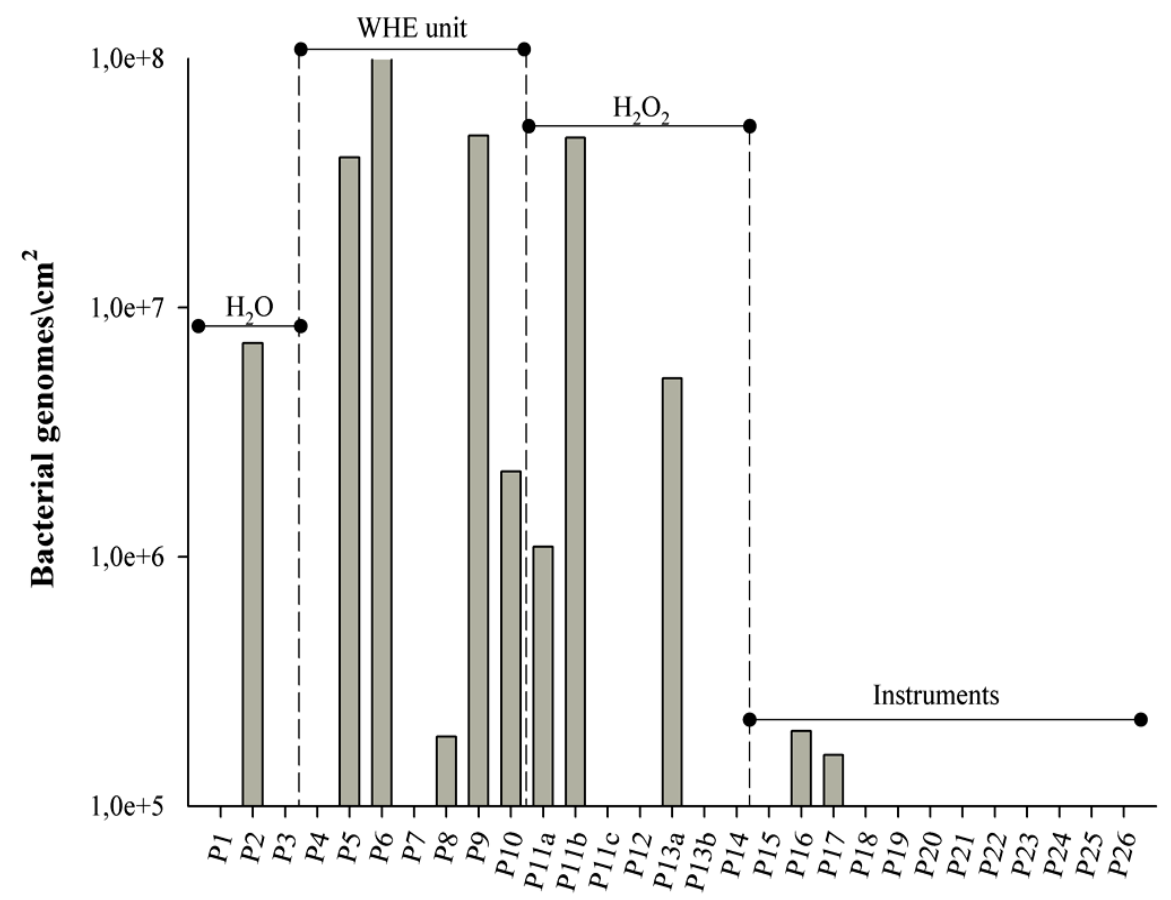

\section{Specimen point}

Fig. (4). Geometrical mean of representative biofilm mass, recognized after 4 weeks, inside the DUWL after contamination with four bacteria : E. coli, P. aeruginosa. S. faecalis and S.aureus, in the absence of any $\mathrm{H}_{2} \mathrm{O}_{2}$ treatment.

attention for prophylactic measures such as: autoclaving of handpieces, handpiece replacement between patients, flushing of the unit prior to use and anti-contamination devices to prevent retrograde aspiration of oral secretions into the water supply line.

\section{ACKNOWLEDGEMENTS}

This work was supported by Cefla Dentale SPA and by a grant from the Università degli studi di Cagliari "start-up giovani ricercatori”.

\section{REFERENCES}

[1] Molinari JA. Dental unit water contamination. Compend Contin Educ Dent 1999; 20(4): 358-62.

[2] Szymanska J, Sitkowska J, Dutkiewicz J. Microbial contamination of dental unit waterlines. Ann Agric Environ Med 2008; 15(2): 173-9.

[3] Uzel A, Cogulu D, Oncag O. Microbiological evaluation and antibiotic susceptibility of dental unit water systems in general dental practice. Int J Dent Hyg 2008; 6(1): 43-7.

[4] Tippett BF, Edwards JL, Jenkinson HF. Bacterial contamination of dental unit water lines--a possible source of cross-infection. N Z Dent J 1988; 84(378): 112-3.

[5] Barbeau J, Gauthier C, Payment P. Biofilms, infectious agents, and dental unit waterlines: a review. Can J Microbiol 1998; 44(11): 1019-28.

[6] Szymanska J. Biofilm and dental unit waterlines. Ann Agric Environ Med 2003; 10(2): 151-7.

[7] Davey ME, O'Toole GA. Microbial biofilms: from ecology to molecular genetics. Microbiol Mol Biol Rev 2000; 64(4): 847-67.

[8] Watnick P, Kolter R. Biofilm, city of microbes. J Bacteriol 2000; 182(10): 2675-79.

[9] Shigeta M, Tanaka G, Komatsuzawa H, Sugai M, Suginaka H, Usui T. Permeation of antimicrobial agents through Pseudomonas aeruginosa biofilms: a simple method. Chemotherapy 1997; 43(5): $340-45$.
[10] Coleman DC, O'Donnell MJ, Shore AC, Russell RJ. Biofilm problems in dental unit water systems and its practical control. J Appl Microbiol 2009; 106(5): 1424-37.

[11] Ozcan M, Kulak Y, Kazazoglu E. The effect of disinfectant agents in eliminating the contamination of dental unit water. J Oral Rehabil 2003; 30(3): 290-4.

[12] Linger JB, Molinari JA, Forbes WC, Farthing CF, Winget WJ. Evaluation of a hydrogen peroxide disinfectant for dental unit waterlines. J Am Dent Assoc 2001; 132(9): 1287-91.

[13] Brudzynski K. Effect of hydrogen peroxide on antibacterial activities of Canadian honeys. Can J Microbiol 2006; 52(12): 1228-37.

[14] Glockmann E, Wiesner J, Oehring H, Glockmann I. Antibacterial efficiency and toxicity of hydrogen peroxide and other antiseptics. Dtsch Stomatol 1990; 40(11): 462-3.

[15] Tschernjawskaja MA, Belowa AS. Antibacterial mechanism of action of hydrogen peroxide preparations. Z Gesamte Hyg 1990; 36(2): 86-8.

[16] Feuerstein O, Moreinos D, Steinberg D. Synergic antibacterial effect between visible light and hydrogen peroxide on Streptococcus mutans. J Antimicrob Chemother 2006; 57(5): 872-6.

[17] Choi YS, Shin DH, Chung IY, Kim SH, Heo YJ, Cho YH. Identification of Pseudomonas aeruginosa genes crucial for hydrogen peroxide resistance. J Microbiol Biotechnol 2007; 17(8): 1344-52.

[18] Glynn AA, O'Donnell ST, Molony DC, Sheehan E, McCormack DJ, O'Gara JP. Hydrogen peroxide induced repression of icaADBC transcription and biofilm development in Staphylococcus epidermidis. J Orthop Res 2009; 27(5): 627-30.

[19] Mai-Prochnow A, Lucas-Elio P, Egan S, et al. Hydrogen peroxide linked to lysine oxidase activity facilitates biofilm differentiation and dispersal in several gram-negative bacteria. J Bacteriol 2008; 190(15): 5493-501.

[20] Szymanska J. Antifungal efficacy of hydrogen peroxide in dental unit waterline disinfection. Ann Agric Environ Med 2006; 13(2): 313-7.

[21] Zanetti F, De Luca G, Tarlazzi P, Stampi S. Decontamination of dental unit water systems with hydrogen peroxide. Lett Appl Microbiol 2003; 37(3): 201-6.

[22] Wirthlin MR, Marshall GW, Jr., Rowland RW. Formation and decontamination of biofilms in dental unit waterlines. J Periodontol 2003; 74(11): 1595-609. 
[23] Denotti G, Piga R, Montaldo C, et al. In Vitro Evaluation of Enterococcus faecalis Adhesion on Various Endodontic Medicaments. Open Dent J 2009; 3: 120-4

[24] Walker JT, Bradshaw DJ, Finney M, et al. Microbiological evaluation of dental unit water systems in general dental practice in Europe. Eur J Oral Sci 2004; 112(5): 412-8.

[25] Porteous NB, Redding SW, Jorgensen JH. Isolation of nontuberculosis mycobacteria in treated dental unit waterlines. Oral Surg Oral Med Oral Pathol Oral Radiol Endod 2004; 98(1): 40-44.

[26] Porteous NB, Partida MN. The effect of frequent clinical use of dental unit waterlines on contamination. N Y State Dent J 2009; 75(3): 20-4.

[27] Ching B. Dental unit water line maintenance. Hawaii Dent J 2005; 36(3): 10 .
[28] Recommended infection-control practices for dentistry, 1993. Centers for Disease Control and Prevention. MMWR Recomm Rep 1993, 42(RR-8): 1-12.

[29] Szymanska J. Microbiological risk factors in dentistry. Current status of knowledge. Ann Agric Environ Med 2005; 12(2): 157-63.

[30] Montebugnoli L, Sambri V, Cavrini F, Marangoni A, Testarelli L, Dolci G. Detection of DNA from periodontal pathogenic bacteria in biofilm obtained from waterlines in dental units. New Microbiol 2004; 27(4): 391-7.

[31] Al-Hiyasat AS, Ma'ayeh SY, Hindiyeh MY, Khader YS. The presence of Pseudomonas aeruginosa in the dental unit waterline systems of teaching clinics. Int J Dent Hyg 2007; 5(1): 36-44.

[32] Mills SE. The dental unit waterline controversy: defusing the myths, defining the solutions. J Am Dent Assoc 2000; 131(10): 1427-41.

Received: November 13, 2009

Revised: February 15, 2010

Accepted: February 25, 2010

(C) Orrù et al.; Licensee Bentham Open.

This is an open access article licensed under the terms of the Creative Commons Attribution Non-Commercial License (http://creativecommons.org/licenses/by-nc/3.0/) which permits unrestricted, non-commercial use, distribution and reproduction in any medium, provided the work is properly cited. 